Article

\title{
Exceptional Injustice: Facebook as a Reflection of Race- and Gender-Based Narratives Following the Death of George Floyd
}

\author{
Patricia J Dixon and Lauren Dundes* \\ Department of Sociology, McDaniel College, 2 College Hill, Westminster, MD 21157, USA; pjdixon7@gmail.com \\ * Correspondence: ldundes@mcdaniel.edu
}

Received: 16 November 2020; Accepted: 8 December 2020; Published: 15 December 2020

check for updates

\begin{abstract}
Following the death of George Floyd, Facebook posts about the Black Lives Matter movement (BLM) surged, creating the opportunity to examine reactions by race and sex. This study employed a two-part mixed methods approach beginning with an analysis of posts from a single college student's Facebook newsfeed over a 12-week period, commencing on the date of George Floyd's death (25 May 2020). A triangulation protocol enhanced exploratory observational-archival Facebook posts with qualitative data from 24 Black and White college students queried about their views of BLM and policing. The Facebook data revealed that White males, who were the least active in posting about BLM, were most likely to criticize BLM protests. They also believed incidents of police brutality were exceptions that tainted an otherwise commendable profession. In contrast, Black individuals commonly saw the case of George Floyd as consistent with a longstanding pattern of injustice that takes an emotional toll, and as an egregious exemplification of racism that calls for indictment of the status quo. The exploratory data in this article also illustrate how even for a cause célèbre, attention on Facebook ebbs over time. This phenomenon obscures the urgency of effecting change, especially for persons whose understanding of racism is influenced by its coverage on social media. The need to recognize the divergence of views-how they vary by sex and race and their connection to social media-remains critical for progress in determining the best steps forward in race relations and police reform.
\end{abstract}

Keywords: Black Lives Matter; BLM; George Floyd; social justice; Facebook; social networking sites; racial justice; unity; protests; race; gender; police brutality; excessive force; bad actors; social media

\section{Introduction}

With the growing role of social media as a source of news (Anspach 2017; Boczkowski et al. 2018; Fletcher and Nielsen 2018; Hopp et al. 2020), videos of violence by police posted on social media have become an increasingly prominent source of hashtags and an impetus for mobilizing social justice movements (Anderson 2016; Bowman 2017; Clark et al. 2017; Lake et al. 2018). Social media sites such as Facebook are one means to rally the public (Miethe et al. 2019), allowing users to discuss police brutality in online settings, independent of an incident's coverage in traditional media (Bordonaro and Willits 2018; Umamaheswar 2020). A bystander video posted on Facebook brought public attention to the killing of George Perry Floyd, Jr., in the twilight hours of Memorial Day, 25 May 2020. Floyd's death quickly became "an inflection point in the modern civil rights movement", not unlike the galvanizing force of the death of Emmett Till in 1955 (Levitz et al., para. 7). In fact, the image of Till's mutilation that appeared in Jet magazine added unprecedented urgency to a social justice movement that showcased the power of social media (Whitfield 1991). Although Till died at a much younger age (14) than Floyd (46), the widespread distribution of video plainly showing nearly eight minutes of police brutality 
against Floyd resulted in widespread consternation. Social media became a key outlet for outrage and horror as memorials to Floyd sprang up nationwide (Cappelli 2020; Mchunu 2020).

The emergence of video footage, especially viral Black death, is a form of "visible evidence", a growing field of study (Watson 2019). While the repeated exposure to violence portrayed on social media platforms such as Facebook can trigger sadness, anger, and fear (Motley et al. 2020), citizen-posted "visible evidence" of police brutality can also become viral spectacles that undermine the humanity of those victimized. "Reiterating the ubiquity of black death outside of its context" can result in short-term dismay about Black death that undermines the need for structural change (Mohrman and Fischer 2016, para. 13). These viral videos of Black death may have "deadening effects of over-exposure to images that were perhaps once meant to move us" (Juhasz 2016, para. 9), a concern consistent with how interest in a news event tends to wane (as conveyed by the "15 min of fame" expression).

On the other hand, social media provides a means to catalyze a movement, without the costs and infrastructure previously required: "The internet allows...movements to grow dramatically and rapidly, but without prior building of formal or informal organizational and other collective capacities...[with] no need to spend six months putting together a single rally when a hashtag could be used to summon protesters into the streets" (Tufekci 2018a, pp. xii-xiii), or to test out messages on large audiences, enhanced by the ease with which users can validate members of their social network (Tufekci 2018b; Vaidhyanathan 2018).

Following George Floyd's death, there were unprecedented calls for increased scrutiny and cessation of police brutality, specifically the killing of Black men by White police officers (Pannett et al. 2020). These reactions, captured in part by posts on social media, are timely and often unvarnished data that provide a unique window into how race and gender predict reactions to a major social movement. This mixed methods exploratory study examines reactions to Floyd's death on Facebook, with methodological triangulation through supplemental queries posed to a Black-White race stratified convenience sample of 12 male and 12 female college students.

\section{The Death of George Floyd, Jr.}

On 25 May 2020, four Minneapolis police officers were dispatched to a business complaining about a counterfeit $\$ 20$ bill. After Floyd, who "fit the description" of the suspect, was located in a nearby parked car, he complied with a request to exit his vehicle, while repeatedly asking officers not to shoot him. Once police handcuffed Floyd, they tried to place him in their squad car, at which point he resisted, citing his claustrophobia and anxiety. At the same time, he reassured them that he would not harm anyone. Once in the police car, Floyd complained of difficulty breathing, resulting in officers pulling him out of the police car and placing him on the ground. Floyd continued to tell officers that he was struggling to breathe, a health concern that was exacerbated when the senior officer at the scene, Derek Chauvin, pressed his knee on Floyd's neck for nearly 8 min. During this time, Floyd was lying on the pavement in agony, expressing that he could not breathe, saying among other things, "everything hurts". His distress was palpable as he begged for water and twice cried out "Mama" in reference to his mother who had died two years earlier. Chauvin finally removed his knee after Floyd had fallen unconscious, and only at the behest of a paramedic called to the scene. The medical examiner later cited the cause of death as cardiopulmonary arrest related to how law enforcement subdued, restrained, and compressed Floyd's neck (Bailey 2020).

Images of Floyd pleading for relief from the excessive force were captured on video by a bystander and shared widely on social media. Social networking sites such as Facebook filled with commentary about Floyd's death, as it was widely deemed to constitute clear evidence of oppression, in accordance with longstanding claims promulgated by such groups as the Black Lives Matter movement (BLM). Politicians echoed this national (and international) trend of Facebook and Twitter posts following Floyd's death, with specific mentions of "George Floyd" appearing on the Congressional Facebook and Twitter social media accounts of $98 \%$ of Democrats and $75 \%$ of Republicans (Shaw and Widjaya 2020), 
an outgrowth of the ability of social media to galvanize the national discourse about racism (Carney 2016; Wilkins et al. 2019).

\section{The Social Justice Movement}

The outpouring of reactions to Floyd's death revealed that frustration with the treatment of Black people by police had reached a tipping point, eliciting calls for radical reform of the police (e.g., defunding them, giving firing power to civilian review boards) (Acevedo 2020; Russonello 2020), outrage likely exacerbated by the impact of racial capitalism on the COVID-19-caused morbidity and mortality that occurred simultaneously (Pirtle 2020). Despite widespread anger at police, the reactions to Floyd's death also included the view that the reprehensible actions of an isolated individual, a so-called "bad apple", did not truly reflect law enforcement as a whole. Those focusing on rogue police, whose actions are seen as anomalous, reflect a philosophy of psychological individualism, in which culpability rests with an autonomous individual. In the case of police brutality, justice entails punishment of a responsible individual rather than dismantling or significantly changing the system. In other words, according to this way of thinking, Floyd's death resulted from the inhumanity of a corrupt individual rather than because of a flawed, unjust system that advantages some groups over others.

These differences in opinion about the need to reform police vary widely by race: $88 \%$ of Black respondents in a Gallup poll believed major reform is warranted compared to $51 \%$ of White respondents (Crabtree 2020). Understanding these differences, including reactions to police shootings of unarmed Black men, is linked not just to race, but also to racial identity. A strong sense of being White, as well as negative stereotypes about Black individuals, predicts low empathy for Black people subject to excessive force by police (Johnson and Lecci 2020), a finding consistent with a racial disparity in worries about police brutality and the effects of structural racism (Graham et al. 2020; Hehman et al. 2018; Horowitz and Livingston 2016). Likewise, adherence to "masculine honor beliefs", such as allegiance to one's country, is inversely related to seeing police violence against racial minorities as problematic (Stratmoen et al. 2019). Moreover, fragile masculinity is linked to a higher probability of justifying social inequality (DiMuccio and Knowles 2020; Weaver and Vescio 2015).

\section{Facebook Posts as a Social Justice Barometer}

One means of gaining insight into responses to police killings of Black citizens is to analyze social networking sites, in particular Facebook, the site with the largest number of users worldwide (despite the ebb and flow in the number of users as other sites such as Instagram have grown in popularity) (Clement 2020). Although young people report learning about BLM from social media sites such as Facebook (Cox 2017), studies in which Facebook is a source of data are a relatively new addition to research studies. It is possible that the dearth of studies that examine Facebook data is due to unresolved issues surrounding informed consent, a topic that is important to consider in order to protect research subjects whose posts on social networking sites are the subject of studies. Below we address concerns about informed consent relevant to the analysis of Facebook data.

\section{Informed Consent in the Analysis of Facebook Posts}

Although analysis of Facebook posts is widely considered to be a gray area in terms of requiring informed consent, certain criteria have emerged about whether a given project can be classified as exempt observational research that obviates the need for informed consent.

First, because information is on a newsfeed (versus Facebook private messages, for example), the expectation is that this form of social media is in fact designed for a person to have an audience. In fact, arguably data from an online space, such as newsfeed data, are consistent with Institutional Review Board (IRB) norms if the subjects perceive the space as largely public, in line with the site's public "glasshouse structure" (Willis 2019, p. 9). 
In addition, the ability to ask someone to revert to private messaging (PM) implies an understanding that communication can transition from a public to a private forum, where expectations of privacy exist (Moreno et al. 2013). Moreover, regardless of Facebook users' awareness of Facebook policies, their information is not in fact private. Furthermore, there seems to be general awareness of how information is sold to advertisers, including how targeted ads appear based on the content of posts. Thus, the data can arguably be classified as "public" behavior (Moreno et al. 2013).

Second, in the case of this study, views about the BLM movement studied here are opinions of those 18 years and older and do not reveal anything about physical or mental health, nor behaviors. In other words, disclosures of subjects' responses could not reasonably put them at risk of criminal or civil liability. Nor is the research intrusive, but rather involves "passive" analysis of Internet postings versus active involvement in the community, defined by actively participating in communication (Eysenbach and Till 2001).

Third, the qualitative information in this analysis is presented in a manner that protects the anonymity of those making comments; the content of comments presented in this paper are either re-posts, and thus untraceable, or have been reduced to key phrases and general views that could not be traced nor attributed to any one individual, with posts as the unit of analysis rather than individual users. Hence, the comments cannot be linked to subjects, but rather are part of an untraceable collection of observations of public posts.

Federal and state courts have ruled that there is no reasonable expectation of privacy in information individuals post on their Facebook pages, for example in accordance with the court's 2010 decision in Romano v. Steelcase. In this case, the court referenced Facebook privacy policies that unambiguously state that users' posts can be shared, and that sharing in social networking sites is their raison d'être, which otherwise would not exist in the first place (Moreno et al. 2013).

Finally, Facebook terms of service are clear about a lack of expectation of privacy. For example, the following statement appears in Facebook's Terms of Service page, under the section entitled:

Partners who use our analytics services:

We provide aggregated statistics and insights that help people and businesses understand how people are engaging with their posts, listings, pages, videos, and other content on and off the Facebook products. For example, page admins and Instagram business profiles receive information about the number of people or accounts who viewed, reacted to, or commented on their posts, as well as aggregate demographic and other information that helps them understand interactions with their page or account (Facebook 2020).

\section{Background on Study Design and Timing}

This study was originally intended to assess Facebook reactions to publicized cases in which Black people were profiled and killed, such as the 23 February 2020 murder of 25-year-old Ahmaud Arbery. Arbery was a Black jogger in Georgia chased and killed by two White men who mistakenly thought he had burglarized homes in their neighborhood (spawning the viral hashtag "I \#RunWithMaud"). By chance, data collection began on Monday, 25 May 2020, the date that George Floyd Jr. was killed by police (and pronounced dead at a hospital at 9:25 pm). By the following day, 26 May 2020, there was an "outpouring of anger" following the release of a bystander video that showed the (White) senior police officer, Chauvin, kneeling on Floyd's neck. By the evening of May 27 and into May 28, protests became violent. Nationwide and international outrage about the death of Floyd emerged by June 1 (Zurcher 2020), triggering a major social movement that generated an explosion of social media posts. 


\section{Methods}

\subsection{Facebook Feed Data}

Data in this IRB-approved study were collected from the Facebook newsfeed of a White female associate of the first author. This associate is a daily Facebook user. She cites Facebook as the optimal platform to connect to a wide web of family, friends, and professionals, whereas on Snapchat and Instagram, she is connected only to friends. On Facebook, she has connections to a broad array of persons of different ages, races, and backgrounds. She uses Facebook to view and share written information in addition to media, while her other social networking sites are primarily media-oriented (posting photos and videos).

The associate's Facebook (FB) friend group is above average in size at 537 friends (versus the mean number of FB friends: 155 (Omnicore 2020)). However, for this study, 50 FB friends were excluded, as they did not identify as or appear to be either Black or White (that is, were primarily Latino and Asian). The remaining group of friends catalogued for analysis was comprised of $487 \mathrm{FB}$ friends: 269 White females (55\%); 155 White males (32\%); 31 Black females $(6 \%) ; 32$ Black males (7\%). The percentage of the subject's FB friends in college or college educated was $85 \%$, with $92 \%$ falling in the $18-25$ age group.

Beginning on 25 May, the first author began checking the designated Facebook newsfeed every few days in order to log all quantitative and qualitative posts about the Black Lives Matter (BLM) movement by those who could be identified as either Black or White, specifically those surrounding police shootings of Black individuals. For purposes of anonymity and logistical recordkeeping, the number of posts per person was not logged, but rather the total number of posts was used, as well as information on whether they were by Black or White persons and their sex (male or female). Assessments of racial groups were based on the first author's presumptions based on photos (while gender was presumed or commonly designated in a person's public personal information). All BLM-related content was assessed for its support for preserving the current system (the status quo). These posts fall into three broad categories that either directly or indirectly convey that change is not the top priority in response to George Floyd's death. Instead, these posts reflect the notion that reform is at best secondary to the need to work within the current system, overlooking experiences and fears of those disadvantaged by a White hegemonic framework: (1) police brutality reflects bad actors and not systemic flaws; (2) unity and commonalities should be prioritized over differences; (3) protests should be strictly non-violent (operationalized below in Table 1).

Table 1. Facebook (FB) friend comments about Black Lives Matter (BLM), categorized by race and gender (971 total comments by 487 Black and White friends over 12 weeks: 25 May-17 August).

\begin{tabular}{|c|c|c|c|c|}
\hline & $\begin{array}{l}\text { White Males } \\
\text { N = } 150 \text { BLM } \\
\text { FB Comments }\end{array}$ & $\begin{array}{l}\text { Black Males } \\
\text { N = } 201 \text { BLM } \\
\text { FB Comments }\end{array}$ & $\begin{array}{l}\text { White Females } \\
\text { N = 537 BLM } \\
\text { FB Comments }\end{array}$ & $\begin{array}{l}\text { Black Females } \\
\mathrm{N}=83 \text { BLM } \\
\text { FB Comments }\end{array}$ \\
\hline $\begin{array}{l}\text { Percent of comments } \\
\text { supporting status quo out of } \\
\text { all of subgroup comments }\end{array}$ & $26 \%$ & $0 \%$ & $7 \%$ & $2 \%$ \\
\hline $\begin{array}{l}\text { Percent of subject's } \\
\text { FB friends }\end{array}$ & $32 \%$ & $7 \%$ & $55 \%$ & $6 \%$ \\
\hline $\begin{array}{l}\text { Percent of all BLM } \\
\text { comments }\end{array}$ & $15 \%$ & $21 \%$ & $55 \%$ & $9 \%$ \\
\hline $\begin{array}{l}\text { Number of total BLM } \\
\text { comments vs. expected } \\
\text { (relative to proportion of all } \\
\text { FB friends) }\end{array}$ & $\begin{array}{l}47 \% \text { of expected \# } \\
\text { of comments }\end{array}$ & $\begin{array}{c}300 \% \text { of expected \# } \\
\text { of comments }\end{array}$ & $\begin{array}{c}100 \% \text { of expected \# } \\
\text { of comments }\end{array}$ & $\begin{array}{c}150 \% \text { of expected \# } \\
\text { of comments }\end{array}$ \\
\hline
\end{tabular}




\subsection{Follow-Up Query Data for Mixed-Methods Design}

Methodological triangulation involved collecting additional data from traditionally-aged college students at the small, private mid-Atlantic liberal arts institution attended by the student whose Facebook account was analyzed. During the week of 6-13 November 2020, with the assistance of a White male student volunteer who queried White males, the authors and the student volunteer used convenience sampling to collect query data about views of the BLM movement from six members of each of the following demographic groups: White males, White females, Black males, and Black females. There was an $83 \%$ response rate, with busy schedules cited as the reason for declining participation.

After obtaining informed consent, the authors conducted the queries in person, via Zoom, or over email (in part due to the COVID-19 pandemic and students' limited time on-campus). These data served as a means to complement the data from FB trends, rather than to provide a representative sample of each group. These data also offered protections of anonymous reporting in contrast to public, non-anonymous posts that characterize FB data. The two queries were as follows:

1. What are your thoughts about the Black Lives Matter movement?

2. How much do you think that George Floyd's death reflects the need to revamp policing in the US versus the need to screen out individuals who abuse their power?

Because of the open-ended nature of the first question, there was a wide range of responses, a consequence of allowing each respondent to choose the direction they would take with the general, open-ended prompt.

\section{Results from Facebook Newsfeed}

White males were least supportive of BLM ( $26 \%$ made comments critical of BLM, coded as pro-status quo). This percentage was much higher than for White females $(7 \%)$. While Black males were only a small proportion of all of the subject's FB friends $(7 \%)$, they accounted for a far greater proportion of all of the comments on the subject's FB feed (21\%) (see Table 1). This finding is also depicted in chart form to show the adjusted number of FB posts over a 12-week period by Black males, as well as the other three demographic groups (see Figure 1).

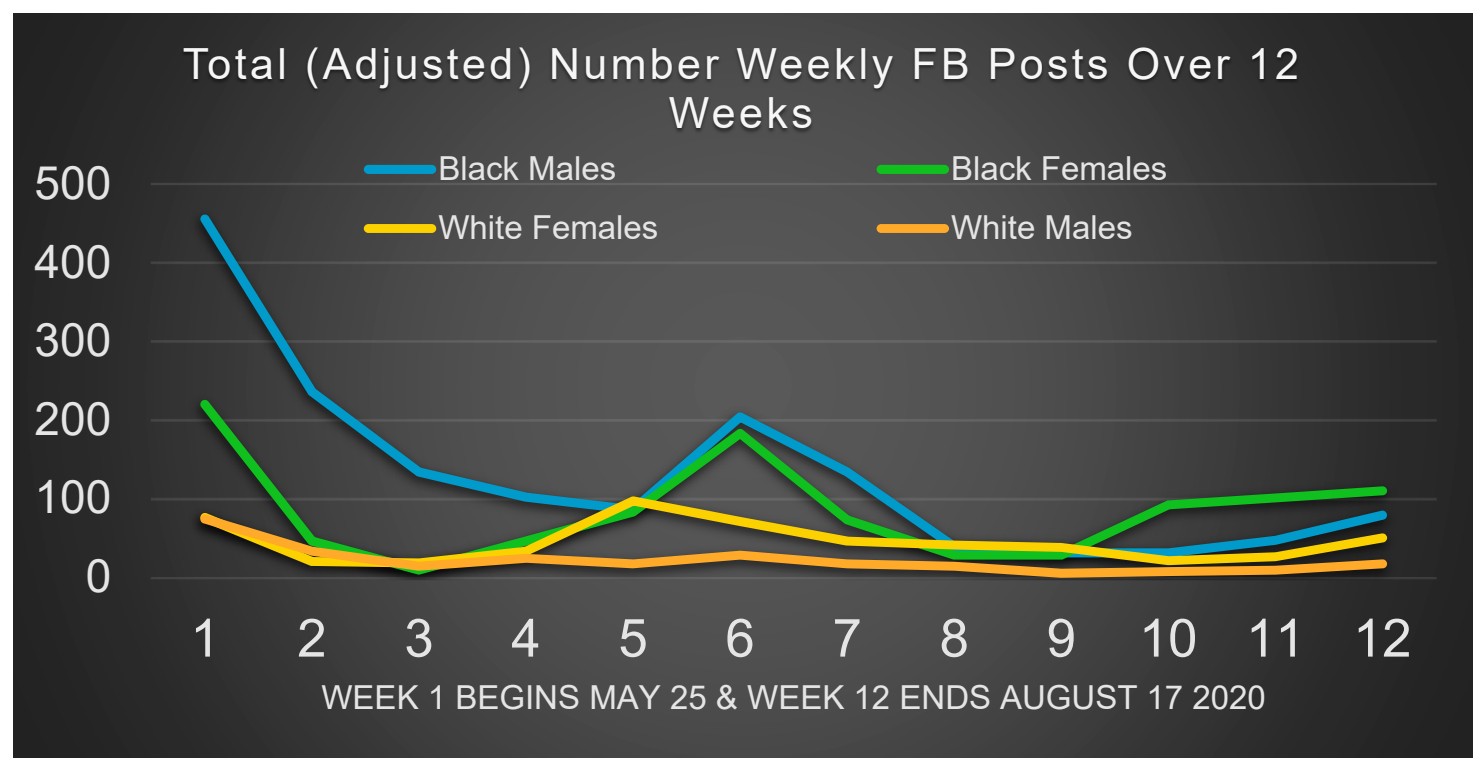

Figure 1. Total (Adjusted) Number Weekly FB Posts Over 12 Weeks. 
To make the number of posts comparable across demographic groups, the number of White female posts was left intact, with the other groups adjusted to take into account their smaller proportions. White males were adjusted by 1.72, Black females were adjusted by 9.17, and Black males were adjusted by 7.86, so that the numbers of posts listed in the chart (below) were derived by taking the recorded numbers of posts and multiplying them by the aforementioned number corresponding to each demographic group.

In week 6, both Black males and females had a resurgence of posts, a pattern that differed from that of White males and females. This week (week 6) covered 28 June-4 July and may have been in response to the ironies of celebrating the country on the 4th of July (Independence Day) when the promise of justice and equality seemed so elusive in the wake of national attention on police killing Black citizens, especially given the way in which George Floyd suffered before his demise. Figure 1 also reveals a substantial drop in online posts in all demographic groups subsequent to week 1 . These data reflect the expected finding that more reactions appeared in the first few days after the Facebook release of the video of Floyd's interaction with Chauvin by a 17 year-old African-American bystander, Darnella Frazier.

\section{Qualitative Data: Comments Supportive of the Status Quo}

Comments, including re-posts, about the BLM movement were analyzed and coded into several broad categories of views supportive of the status quo, some of which are paraphrased to protect posters' anonymity:

(1) Bad actors. In this category of comments, posters expressed the belief that the killing of Black people by police reflected the inevitable "bad apples" or corrupt individuals in an otherwise laudable and necessary social institution.

Examples include the following: (1) Not all cops are bad. (2) Do not let the officer who murdered George Floyd define what you think about law enforcement officers in general. There are so many phenomenal officers out there who put their lives on the line for us every day and they do not deserve the hate. (3) A few bad officers do not mean all officers are evil. (4) Unfortunately cops like this slip through the cracks. (5) \#DontJudgeAllBecauseOfOne.

(2) Unity should supersede racial differences. Posts in this category included the following: (1) "People are people" (suggesting that the George Floyd incident had nothing to do with race-with content revealing the view that the claim that the incident was about race was itself racist). (2) Photo of a Black man hugging a White police officer captioned, "more love, less hate". (3) "We are one race, the human race". (4) "We should all stand together rather than putting each other down". (5) "\#Togetherstrong". (6) Various hashtags: \#allvoicesheard \#alllivesmatter \#standtogether \#commonenemy \#racismistheenemy."

All of these examples reflect the belief that the death of George Floyd should unify all those that oppose police brutality (i.e., virtually everyone). The case then becomes a human rights issue, separate from race or historical patterns of racism.

(3) Focusing on acceptable forms of protest. Posts that exemplified this perspective included the following: (1) "I'm okay with protesting but there's a way to go about it to get your word heard" (including disapproval of the manner in which Colin Kaepernick protested in 2016 when he took a knee during the national anthem at football games). (2) A picture of Martin Luther King, Jr., walking with a group of people with the caption "This is a protest" paired with a picture of looting in Minnesota captioned "This is a crime". (3) Condemning police brutality alongside this message: "Looting and burning businesses is [also] immoral and counterproductive, and people who do this should go to jail". (4) The sentiment that the more violent forms of protest were a setback to the movement, encapsulated by the words, "You are your own worst enemy." 


\section{Qualitative Query Data}

Query data collected subsequent to cataloging the Facebook data provided convenience sample data from 24 student respondents who shared their thoughts, data that respondents knew would be reported anonymously and remain confidential (unlike FB data). There were only two prompts:

1. What are your thoughts about the Black Lives Matter movement?

2. How much do you think that George Floyd's death reflects on the need to revamp policing in the US versus the need to screen out individuals who abuse their power?

(Complete responses for all 24 respondents are available in Appendix A.)

\subsection{White Males}

Three major themes emerged from White males queried, all in line with the FB data: (1) non-peaceful BLM protests, specifically looting and rioting, hurt the movement; (2) the media creates a false narrative that overstates racism; (3) police are wrongly discredited by a few bad apples and instead engage in noble work that deserves to be appreciated. See Table 2 below for a synopsis of respondent query data.

Table 2. Synopsis of six White males' (WM) responses to queries about BLM.

WM 1: Black Lives Matter is a great movement for the Black community to express their feelings. We do need police reform, like requiring more hours of job training, but looting and rioting are not a good solution to the problem of injustice.

WM 2: Police do a good job keeping everyone safe-and some situations that aren't racist get construed that way in the media.

WM 3: This country truly is divided, and it is because of the media trying to push a narrative to benefit only them. We as Americans have failed the very people who protect us on a daily basis, and if we do not fix the divide, we may not have many more police officers willing to protect and serve in this country.

WM 4: The movement promotes the physical destruction of businesses and property in order to send a so-called "message" that is both threatening to our law enforcement officers and other races.

WM 5: I believe that the whole ACAB (all cops are bastards) and defund the police talk is nonsense. What we need to do is invest in our police force and focus on better training for them.

WM 6: I have only seen them protest. I think there are much better ways to solve the issues at hand, revolving around black businesses, education, and fixing communities. There are truly just a few bad apples...[Police] should truly be getting our thanks for putting their lives on the line every day.

\subsection{White Females}

As summarized in Table 3 below, three salient themes emerged among White females: (1) the BLM movement is needed to combat police brutality and racism; (2) the movement has inadvertently created racial divisions that are uncomfortable; (3) it is difficult to know how best to support the movement but learning about it and discussing it are an important step. 
Table 3. Synopsis of six White females' (WF) responses to queries about BLM.

WF 1: A lot of White people can feel helpless as to what to do and how to be an ally. We do need to have police but people of color need to feel safe, even though I don't know what that looks like for them.

WF 2: The BLM movement is entirely necessary for the advancement of equality in policing. We hear "all lives matter", but that can't be possible until systemic racism and implicit biases are removed from all workplaces, and we address the treatment of minorities while interacting with police officers and in the court system.

WF 3: With every movement comes backlash like saying, "all lives matter". That is true but that is not what the movement is trying to say. They weren't bashing other ethnic groups but saying, "Hey, Black people matter too and we are not treated correctly." People need to stop viewing things as blaming them personally.

WF 4: I feel like some followers of the movement have begun to lose their way by criticizing people they think don't support the movement. So while I completely understand BLM and fully support it, it is creating a divide in the nation, rather than the unity that was originally intended.

WF 5: Maybe White people are quiet because we are watching and learning and trying to recognize our "White privilege" we were taught to ignore by society and our families so we can make a change.

WF 6: The movement is doing really good things by addressing people's differences and how everyone should be treated the same no matter what they look like. But too often we hear about all of the negative things that police officers do since the media doesn't show enough of the good things they do daily. However, there is still a need to fix what the police do because they are far from perfect. People should talk more and be better educated about this instead of treating it as taboo and argument-provoking.

\subsection{Black Males}

The query data from Black males stood out in terms of respondents' frustration with the status quo and especially with corrupt officers that compel Black people to stay ever-vigilant against police brutality. Their responses (Table 4) also provide a glimpse of its emotional toll.

Table 4. Synopsis of six Black males' (BM) responses to queries about BLM.

BM 1: We have to combat racism, especially police brutality, which otherwise lets corruption get pushed under the rug. I know people that have been pulled over by police and beaten up so corrupt policing is something on my mind. But we [men] don't talk enough about how this affects us because we aren't in touch with our emotions. My father wouldn't let me watch SpongeBob once he saw that the character cries a lot.

BM 2: We have to act a certain way to be presentable when we go out in public. I have been pulled over for no apparent reason where the cop was going the extra mile just to see if we were doing what we're supposed to be doing. He "thought there was suspicious activity" and checked all of our IDs. There are not a few bad apples-they are everywhere.

BM 3: Inside of the police force, we know that the police protect their own, pretty similar to how gang members don't believe in snitching. But it was good to see that people genuinely cared about what happened. It made me feel positive about the future, seeing that police reform is starting to come to the forefront of people's minds and people aren't defending police as much anymore.

BM 4: The police have always known that they have back up from other officers and feel empowered to abuse their power. Defunding them takes back control for Black neighborhoods where residents are used to fighting for their rights in a system that works against them but always stands behind police. Defunding them puts community residents on more equal footing with police in a system that doesn't have our back.

BM 5: The BLM movement is inspirational, but unfortunately I see a majority of it as a trend when it needs to be an everyday thing. Black lives certainly do matter, yet we continue to have to say, "Oh look! There goes another Black person murdered, missing, or lynched," and it's exhausting. I truly hope that one day society will just be able to recognize African Americans as equal. Because it is draining, it is very draining.

BM 6: BLM is a necessary movement Black people have been fighting for a really long time, pointing out the injustices that they face on a day-to-day basis, and how they are endangered every single day. People get really impassioned about being a part of protests, to feel like they belong. I saw White girls dressed with helmets and bats at a protest, like it was a block party. People don't really know why they are there. To make people in positions of power uncomfortable, we have to continuously educate and have these conversations. We have to pound the pavement to make sure that people don't forget about it because that interest dies off. 


\subsection{Black Females}

The three most prominent themes Black females expressed (Table 5) were: (1) frustration that Black people's lives have not been valued, historically or currently; (2) the need for mainstream acknowledgement that fighting racism must be prioritized; (3) White people need help understanding that the true meaning of the movement is equality and not Black superiority.

Table 5. Synopsis of six Black females' (BF) responses to queries about BLM.

BF 1: Some people don't realize the long-standing tension that has gotten pushed to the background as normal, so it's hard for them to see it, like when Black people get labeled as thugs. History is repeating itself.

BF 2: People need to understand that BLM isn't saying that black people's lives matter more than others; it's saying that they should be valued as much as anyone else.... because we feel that we're not advocated for in society. BLM isn't about dividing the country, but about uniting it. It's a shame that it took Floyd's death for people to realize that things have been happening like this for a long time.

BF 3: Our lives should matter all the time, regardless of the involvement of an authority figure like a police officer or the race of the killer. We should be as upset by Black on Black deaths, even when it gets less media attention.

BF 4: BLM allows racial issues that were once taboo to transform into mainstream topics for the masses. George Floyd's death represented the systemic abuse of black people, which leads to our militarized police taking extreme and unneeded action. George Floyd's death is one of the countless deaths of an innocent African American in 2020 alone.

BF 5: The Black Lives Matter movement is simply a movement to increase awareness of the growth in killings of Black men and women when compared to any other race, whether it's due to police brutality or murders of Black men and women by civilians...[a] problem that a lot of people want to ignore.

BF 6: As Black people, we also get questioned because we don't get a basic level of respect or credibility, but we mostly need the movement because of how White police officers treat Black people. I have to think extra hard when I encounter police because I go in with the idea that they could harm me rather than protect me.

\section{Discussion}

Analysis of 12 weeks of FB posts and query data uncovered two patterns that will be the focus of the discussion: (1) how White males were least likely to post about BLM and most likely to cite the role of bad apples in explaining Floyd's death and (2) the relatively high number of posts by Black males.

\subsection{White Men and Support for the Status Quo}

FB comments by White males were less apt to be unilaterally supportive of the BLM movement, although it is important to point out that nearly three-quarters of FB posts by White men were supportive of BLM and that the comments favoring the status quo often revealed conditional support for the movement. While the data could reflect that White males feel defensive because publicized police shootings often involve Black male victims shot by White male officers, the data suggest additional reasons that White males were less likely to both see and speak out against racism.

\subsubsection{Police Brutality and Bad Apples}

White males were more likely than other demographic groups to blame the media for overstating police brutality and distorting the honorable nature of police. WM 6 commented, "I have met many police officers in my life and all of them are fantastic people" (emphasis added). This is in sync with research by Levan and Stevenson (2019), who examined both social media news sources (most prominently Facebook) and data on college student views of police comportment. They found that White males justified law enforcement's behaviors in part by faulting victims' lack of compliance and how the media conveys the narrative, findings consistent with the query data from White males in this study. For example, Levan and Stevenson found that students largely questioned the accuracy of media 
portrayals, e.g., a White male in their study commented that the few "bad apples" are disproportionately featured, wherein a single incident "gets blown up" (Levan and Stevenson 2019, p. 95).

\subsubsection{Riots and Looting}

One of the most striking facets of the query data from White men was their greater likelihood of seeing Black protestors as vandals (e.g., citing looting and rioting in accordance with the thug stereotype (see Smiley and Fakunle 2016)) (see Table 2 and White males in Appendix A). While other demographic groups saw the riots and looting as exceptions to meaningful protests, the White males were more prone to seeing police brutality as exceptional. Prioritizing law and order and seeing police officers as heroes maintain the status quo in which White males have traditionally been in power. White males, then, are more inclined to view the BLM movement as threatening, attracting people willing to flout the rules because they do not trust the police. Thus, protestors are perceived as disrespecting law and order-a cornerstone of a system that has helped White people maintain hegemony.

White males may be more apt to think that they should be masters of their reality and experiences due to an internal locus of control. By downplaying social forces and emphasizing the power of the individual, they could be more likely to attribute problems with the police as primarily driven by the individual's actions rather than by racism that results in differential treatment of people of color. Attributing police brutality to bad apples or bad actors is in line with the fundamental attribution error, that is, thinking that the actions of a corrupt or sadistic individual do not reflect an institution or broader social forces that shape an individual. Furthermore, with less socialization of males to be empathetic, it may be more difficult for White males to imagine what it would feel like to experience the dangers of living as Black men, who according to racial stereotypes, are more likely to pose a threat than be a victim.

In other words, White men have a vested interest in conceiving of the video of a White police officer killing a Black man as one autonomous man killing another man, neither of whom represent a demographic group. Instead, they may view the video as depicting a flawed police officer whose actions occur outside a racialized context. Ignoring a pattern helps them avoid seeing themselves in the video; they do not want to recognize themselves as the oppressor or part of a racial group that exerts hegemony. The incident is not seen as a microcosm of racism but rather as a manifestation of the failings of a corrupt individual whose race and gender are irrelevant and hence do not reflect broader societal issues based in social structural inequality (Watson et al. 2020). ${ }^{1}$

The flip side of social structural inequality is undeserved White privilege. The bad actor paradigm frees White individuals from implications about unfairly benefiting from race and gender because of an unjust system. The system and the status quo can then be preserved. The emphasis on the individual allows White men to blame autonomous bad actors that make the pattern irrelevant to them as unique individuals. Seeing abusive police as deviants reflects the belief in people acting as free-minded persons (Fowler and Geers 2017). At the same time, this mindset preserves a system that condones inequality that benefits them. Thus, White men have a vested interest in blindness to patterns and systemic social forces that show White males acting as oppressors and Black individuals suffering the consequences.

While the video of Floyd's treatment removes any justification of police action as self-defense, White men seeing the corrupt officer as an anomaly obviates the need for introspection about the role of a biased system in which White men hold a position of advantage. This bad actor mentality is also encouraged by a culture of toxic masculinity that is so prevalent that it is hard to see (Vandello and Bosson 2013). Men are valorized for having agency and dominance, and sometimes for

1 Blindness to social inequality also emerged in the weeks following 9/11/2001, when White Americans put up flags in a show of patriotism, while many Black people failed to see how an act of terrorism erased social structural inequality and merited an abrupt show of unity in the absence of societal reform (Harlow and Dundes 2004). 
being a maverick or a lone wolf, in contrast to women being praised for ensuring their actions meet with the approval of others, reflecting women's socialization to be interdependent (Cross and Madson 1997). If White men perceive themselves as independent of a system because they ostensibly operate outside of it, then it follows that they would lack a direct role in or the responsibility for fixing social structural inequality. Nor would they feel compelled to take ownership of the anomalous bad actors that must be separated from an otherwise admirable police force.

\subsection{White Females}

In contrast, White women expressed more empathy for those victimized by police brutality, yet they also prioritized unity. By seeking to minimize divisions, regardless of persistent and entrenched racial inequality, they arguably validated concerns that White participation is driven in part by social justice as an in-vogue activity (Stewart 2020), as expressed by BM \#6: "I saw White girls dressed with helmets and bats at a protest, like it was a block party. People don't really know why they are there" (Table 4). These concerns are an echo of suspicions that for White women who attended the Women's March in January 2017, promoting social justice can be performative (Brewer and Dundes 2018). Two other Black males also queried expressed wariness about White people's long-term commitment to change: "You see White support when the issue is trending, but not after the moment has passed" (BM 4, Table 4), and "The BLM movement is inspirational, but unfortunately I see a majority of it as a trend when it needs to be an everyday thing" (BM 5, Table 4).

\subsection{Black Males}

Black males' concerns about the transitory nature of White support for BLM are consistent with their strong support for the movement, which is reflected in the FB data. Black men spoke up disproportionately more than their share of the subject's FB friends (7\% of FB friends and $21 \%$ of all BLM posts, contrasting with White men who spoke up less than might be expected, comprising $32 \%$ of FB friends but only $15 \%$ of all BLM posts). The data presented as weekly posts (see Figure 1) show that Black males were significantly more likely to post than all of the other groups. This gave them an opportunity to change the narrative from identifying with a victim of police brutality to that of a social reformer taking control and demanding change. This general phenomenon of empowerment has been noted with Twitter data, where tweeting is used to call for social change through political participation (more than disruptive protesting) (Tillery 2019) (while hashtags are associated with partisan views (Rho and Mazmanian 2019)).

The data, however, do not answer the question of why the death of George Floyd galvanized people-Black men in particular, according to Facebook data presented in this paper. Floyd's death, as described by Black writer Jemar Tisby, triggered a "shared sense of danger that made us [Black men] feel like more than friends-we were brothers" (Tisby 2020, para. 3), solidarity that Tisby notes also emerged when former President Barack Obama reacted to the death of Trayvon Martin saying, "This could have been my son". Obama's statement about Trayvon Martin that helped spawn the Black Lives Matter movement in 2013 reveals that such deaths united Black individuals despite differences in social class, promoting solidarity through hardship "forced on us by the oppression we endure in a White-supremacist society" (Tisby 2020, para. 6), and in a society in which "African Americans are not granted the same privileges as their White peers in terms of emotional display" (Jackson 2018, p. 1).

Beyond a feeling of kinship with victims of police brutality, some Black men may see themselves when contemplating the fate of George Floyd, given the high proportion of Black men who have experienced racism, and therefore distrust police (Calvert et al. 2020), a sentiment reflected in the query data (see Table 4). However, speaking up and complaining are generally not socially sanctioned for Black men, who must consider the costs of alienating White people (Mincey et al. 2015) and avoid an appearance of vulnerability. Some Black male respondents mentioned the emotional weight they carry, including pressure to hide signs of vulnerability. For example, BM 1 shared that he was socialized to contain his emotions: "My father wouldn't let me watch SpongeBob once he saw that the character 
cries a lot". Similarly, BM 2 was very aware of his front stage persona: "We have to act a certain way to be presentable when we go out in public" (see Table 4).

Furthermore, previously published data from the same institution where query data were collected reveal that Black men may be reluctant to admit feeling vulnerable, even though they are the most likely to be victims of police brutality. These previous findings show that Black female college students were much more likely than Black male college students to feel very vulnerable when thinking about police shootings of unarmed Black people (45\% versus 25\%) (Robertson and Dundes 2017, p. 8). Nonchalant performativity exists within what Erving Goffman labels a "front stage" public performance that co-exists with "backstage" anger (Goffman 1959; Jackson and Wingfield 2013). However, in this particular case of police brutality with Floyd, vocalizing and going public with such sentiment seems to have been socially sanctioned, possibly providing a reprieve in the intense pressure to engage in impression management. For example, although not all posts showed empathy for Floyd, there was no blatant evidence that anyone in the sample studied (including White males) directly or indirectly disparaged Floyd's patent display of suffering. In fact, Floyd expressed fear and pain-and did so in front of police officers, in an exhibition of vulnerability that men are socialized to hide, especially when in the presence of adversarial agents of social control (Fowler and Geers 2017). Floyd revealed his anxiety and apprehensions about his fate, showing no macho aggression, but rather only agony, including a memorable and haunting cry invoking his departed mother. When Floyd called out for his mother, some perceived his cries to be a type of sacred invocation ( $\left.\mathrm{O}^{\prime} \mathrm{Neal} 2020\right)$, an interpretation bolstered by Floyd's belly tattoo of his mother's name (Fernandez and Burch 2020; Levitz et al.).

Instead of condemning these behaviors as a failure to demonstrate masculinity publicly (Vandello and Bosson 2013) or in an aggressive manner (O'Dea et al. 2018), Floyd's suffering garnered support for causes advanced by BLM, in an unprecedented way, at least as measured by reactions on social media. In other words, Floyd's vulnerability was touted as a strength, as brave, because instead of disguising his pain, his voice was heard and was audible around the world. He was recognized, indeed canonized, for his suffering in the absence of aggression; murals and other depictions of his likeness included halos and angel wings. As a result, the circumstances and narrative surrounding his death became a symbol of the oppression of Black men, giving other Black men license to show pain and vulnerability through social media posts. All of these factors may have coalesced to increase social acceptance of Black male FB posters expressing vicarious pain and outrage about Floyd's death (Small 2020).

\subsection{Black Females}

The Black women queried were conscious of how White people perceived the BLM movement, revealed in part by the hope that White individuals see BLM as a movement to advance equality rather than to promote Black superiority. Some query data reflected Dubois' double consciousness in Black female respondents seeing themselves as supporters of the movement through the eyes of White people that misunderstand the movement. The Black women queried largely wanted to convey that the movement is one promoting unity (Appendix A). Thus, they carried the double burden of worrying about their vulnerability to police brutality as well as concerns that White people could misunderstand the movement as divisive or threatening.

\subsection{Broader Context for Study Findings}

These racially disparate sentiments are not unexpected. Robertson and Dundes (2017) found that White college students were less likely than Black college students to feel very distrustful of police (10\% of White males and $17 \%$ of White females compared to $32 \%$ of Black males and $45 \%$ of Black females). Likewise, according to research by Pew, most Black respondents (just over $60 \%$ ) considered race to be a major factor in the grand jury decisions not to indict the officers responsible for the shooting deaths of Michael Brown and Eric Garner compared to 18\% of White respondents (2014). This phenomenon is related to greater White indifference to police killings, wherein White people studied focus on the "if 
only" aspects of the incidents: "If only Michael Brown hadn't stolen the cigarillos, Trayvon Martin hadn't been walking with his hood up in that neighborhood, or Tamir Rice hadn't been playing with a toy gun" (Reinka and Leach 2017, para. 40), narratives in which sympathy is subject to media bias (Torres 2003).

\subsection{The Lens of Race and Promoting Action}

These finding raise the question of what to do about these varying perspectives about BLM and police brutality. Some insight lies in how police brutality is publicized and how it affects individuals based on their race. "When we have the choice to look, we are bound ethically and politically to what we witness and what we do with all we have seen" (Juhasz 2016, para. 7). However, White people may process police brutality against Black people differently because of disaggregation, a "narrative technique that narrows the perception of the range of illegitimate racial power by divorcing particular episodes from their larger social context", as occurred in the Rodney King case, where King was portrayed as a menace when defense attorneys employed freeze-framed and blurred images, with officers' narration of their point of view that diminished the officers' accountability (Watson 2019, p. 42). When such portrayals feed into negative stereotypes about Black males, there are implications for audience empathy for victims and perpetrators (Dukes and Gaither 2017).

As a result of ignoring the broader socio-historical pattern of racist policing, and in conjunction with negative stereotypes about Black males as criminals (Owusu-Bempah 2017), we can expect White people to minimize the urgency of ethical action by citing the need for training, in which good, trustworthy protectors who deserve appreciation require even more resources to help deal with an allegedly self-sabotaging community (evidenced by any looting and rioting by protestors). Nowhere in the query data from White males was there a sense of the enduring history of police brutality, nor the broader context of structural racism. The mention of rioting and looting, only brought up by White males queried, shows the prioritization of stability (the status quo) over equality. This makes sense within the context of being part of a group that stability benefits and their identification with those that enforce social order.

\section{Limitations}

The data is drawn from a single Facebook user's account, and is, thus, subject to bias based on the demographic profile of the subject (young, White, and educated) (see Barroso 2019 for a discussion of how these factors influence the likelihood of discussing issues surrounding race). In addition, the total number of comments tallied did not reflect the number of participants actively involved in the posts, but rather the overall number of posts within each of the four demographic groups, with presumptions made about how individuals identify racially. Other studies should use a larger pool of FB users, including users with FB friends from racially diverse demographic groups. In addition, Facebook is only one source of commentary about social justice with limited generalizability.

While FB data are not posted anonymously, the follow-up two-question query was reported anonymously. As a consequence, the query data have the potential to be more honest, but are also subject to social desirability bias, based on the rapport of the person collecting the data and the respondent. This bias, however, is hard to escape when researchers take on politically sensitive topics. In addition, the queries supported the trends noted in the Facebook feed, as well as previously published data on a similar topic from the same college (Robertson and Dundes 2017). Conducting research during the COVID-19 pandemic also affected generalizability, as the resulting restrictions on interpersonal interactions and fears about the coronavirus created an unusual environment in which protests about George Floyd's death occurred.

\section{Conclusions}

While White males supported police "reform" (that involves more resources for police-not defunding them), they also stipulated what constitutes a proper protest (i.e., one that is non-violent). 
They also tended to attribute brutal police tactics to a few bad actors rather than systemic racism. These views largely support the status quo. As such, White people can feel virtuous about conditionally endorsing an ostensibly cross-racial, unified effort to address police brutality, but one that ultimately will not interfere with the current power structure. However, understanding different perspectives is a way to stop different groups from talking past each other and to increase empathy, even if it causes White people to be uncomfortable.

Bernice King, daughter of Martin Luther King, Jr., tweeted on 23 August 2020: “We shouldn't have to see one more video of a Black human being brutalized and/or gunned down by police in a clear case of excessive or unwarranted force. Anybody who doesn't believe we are beyond a state of emergency is choosing to lack empathy and awareness" (King 2020). King's use of the word empathy is consistent with the data in this paper showing that White men are least empathetic about social justice challenges. However, it is important to emphasize that the bad actor paradigm does not apply to all White males, but rather provides some confirmatory evidence of which demographic group is most resistant to social reform.

Darnella Frazier, who posted the video of Derek Chauvin's assault on George Floyd on Facebook, posted a meme of Boondock's character Huey Freeman on 10 November 2020 that reflects the frustration Black individuals feel towards White people's criticism of the movement:

"I have no patience for White people trying to lecture us on how to respond to oppression in the comfort of their own privilege." ${ }^{2}$

The data in this study elucidate the context for this statement. Greater awareness of demographic patterns in reactions to injustice could help increase momentum for achieving racial justice.

Author Contributions: Both authors contributed equally to each stage of the research with the exception of the collection of the Facebook data by P.JD. All authors have read and agreed to the published version of the manuscript.

Funding: This research received no external funding. APC charges were covered in part by a Charles A. Boehlke, Jr. Engaged Faculty Fellow grant.

Conflicts of Interest: The authors declare no conflict of interest.

\section{Appendix A}

\begin{tabular}{|c|c|}
\hline \multicolumn{2}{|c|}{ Answers to Queries: } \\
\hline & What are your thoughts about the Black Lives Matter movement? \\
\hline & $\begin{array}{l}\text { How much do you think that George Floyd's death reflects on the need to revamp } \\
\text { policing in the US versus the need to screen out individuals who abuse their power? }\end{array}$ \\
\hline \multicolumn{2}{|c|}{ WHITE MALE DATA } \\
\hline WM \#1 & $\begin{array}{l}\text { Black Lives Matter is a great movement for the black community to express their } \\
\text { feelings. White people should try to understand what Black people have gone } \\
\text { through. We do need police reform, like requiring more hours of job training, } \\
\text { but looting and rioting are not a good solution to the problem of injustice. }\end{array}$ \\
\hline WM \#2 & $\begin{array}{l}\text { I support the purpose of the movement, but I do not support the way that some } \\
\text { people are going about their protesting. I think that the peaceful protests are great to } \\
\text { bring awareness, but I do not support the rioting and looting. We need more funding } \\
\text { for the police department so that they can be better trained on everything that they } \\
\text { will encounter, but generally police do a good job keeping everyone safe-and some } \\
\text { situations that aren't racist get construed that way in the media. }\end{array}$ \\
\hline
\end{tabular}

2 https://www.facebook.com/darnellareallprettymarie. 

anything. I believe that Black lives in fact do matter, but the movement is not something I can support. Since the movement has started, it has caused millions of dollars in property damage around the United States and countless deaths of police officers and civilians. There have been riots in major cities that have affected the lives of more Black people than any others. I believe that there have been some good protests but when they turn into riots, they immediately are counterproductive. I just do not get it because Black Lives Matter is supposed to support racial equality and bring an end to systematic racism but they only care about their own agenda.

During the riots after George Floyd's death, a black 77-year-old retired police officer was shot for protecting a small business. Do black police officers' lives not matter? Or only the black lives that fit the narrative? People are so blinded and taken over by the media that they do not see how much pain the riots are causing. You can have a protest without it turning violent. I have seen videos of White liberals harassing black police officers for being a police officer. If you actually watch interviews in the inner city where the riots take place, the residents love the police and do not want them defunded because they know they need the police to protect their neighborhood. This country truly is divided, and it is because of the media trying to push a narrative to benefit only them. We as Americans have failed the very people who protect us on a daily basis, and if we do not fix the divide, we may not have many more police officers willing to protect and serve in this country.

It was a shame that George Floyd died the way he did and the police officer who killed him should be put away for it. But Floyd was resisting arrest as seen in the bodycam footage where he was in the police car and then pushed himself out of it, claiming he was claustrophobic. There have also been reports that there was fentanyl in his system. If that was the case, he had a very high percent chance of dying. I do not think there is any need to revamp law enforcement, but I do believe we must hold police officers accountable more. We are now moving out of the old generation of police officers adding more and more new young police officers. The older generation grew up where racism was more pronounced, but the younger generation is people like us. As we grow older, everyone will become more accepting and the racial divide will close. What we need in the United States is to form a stronger bond between law enforcement and the newer generations. This will make them more trusting and lower crime.

WM \#4 The Black Lives Matter movement is a discriminatory and politically inaccurate movement that promotes the superiority of one ethnic group rather than equality. While it is not a "terrorist group", the movement promotes the physical destruction of businesses and property in order to send a so-called "message" that is both threatening to our law enforcement officers and other races.

George Floyd's death simply gave the gang members and criminals that live in the ghettos of Minnesota a reason to riot and loot small businesses and the use of strong force should be heavily imposed. They are destroying their own neighborhoods and Black businesses, and then are the first to complain after they have rioted. There are other ways to solve this concern, specifically enforcing stricter and longer police training to become a cop.

I support everyone being treated equally. If people took the time to do their research, they'd be surprised to find out that more White Americans are killed by the police each year than Black Americans. What would happen if you did defund the police? Then who are you going to rely on? It is simply the most racist and dumbest group that I have ever seen organized over recent years-to treat all cops as "pigs" and anyone who doesn't support the movement as "racist". With people such as Breonna Taylor dying, she was at the wrong place at the wrong time. It isn't the police's fault. If her boyfriend had never shot at the police, there wouldn't have been police gunfire. I guarantee you that the police validated themselves before entering the residence, as part of their civic duty. 
WM \#5

In the case of George Floyd, my understanding is that he had a previous history with the police officer, he was on some kind of drug, and he had previous arrests. Now my main question is why does everyone portray Floyd as a hero? I am in no way agreeing with the actions of the police officer or the officers who stood around and let that happen, but I think there is something to be said about Floyd's past and maybe the police officers' knowledge of him. I believe that the whole ACAB and defund the police talk is nonsense as well. Change is necessary but what we need to do is invest in our police force with better training and collaboration with social workers for situations where mental illness is an issue.

WM \#6 The BLM organization likes to pick and choose when lives matter. They are silent when Black police officers are murdered like David Dorn. They are silent about the millions of Black babies that have been killed through abortion. They are silent when it comes to promoting successful Black conservatives like Candace Owens. They are silent when it comes to the rampant crime in Black communities. They receive millions of dollars in support from shadow donors like George Soros and seem to only participate in movements when there is politics involved. I cannot personally point to a situation that they have made better. I have never heard about that organization trying to help their communities. I have only seen them protest. I think there are much better ways to solve the issues at hand, revolving around black businesses, education, and fixing communities.

There are truly just a few bad apples. I have met many police officers in my life and all of them are fantastic people. The entire group is being judged on the basis of Derek Chauvin and men like him when they should truly be getting our thanks for putting their lives on the line every day. If we provided more training and services like therapy to these officers, it would be more beneficial than to get rid of the system.

\section{BLACK MALES}

$\mathrm{BM} \# 1$

BLM is a very influential, essential movement. It is a continuation of past efforts-a modern version for a newer generation where more people are coming together as a whole. We have to combat racism, especially police brutality, which otherwise lets corruption get pushed under the rug. We need to completely re-do the system and stop prosecuting Black people for minor, petty offenses, especially drug offenses that lead to unnecessary incarceration.

I know people that have been pulled over by police and beaten up so corrupt policing is something on my mind. But we [men] don't talk enough about how this affects us because we aren't in touch with our emotions. My father wouldn't let me watch SpongeBob once he saw that the character cries a lot, telling me, "You're not going to be a crybaby" because, "crying isn't going to help you get through a problem".

BM \#2 At around 12 or 13 years old, I went to a friend's house and his dad (Black) explained to me the double standard where we have to act a certain way to be presentable when we go out in public. I have been pulled over for no apparent reason where the cop was going the extra mile just to see if we were doing what we're supposed to be doing. He "thought there was suspicious activity" and checked all of our IDs. The biggest thing about BLM movement is that it's unified. It's joining people from different areas together. Looking at the George Floyd situation was frustrating-there were other cops around, seeing him get choked out. There are not a few bad apples-they are everywhere. I can't forget the San Francisco 49ers' “blackout Tuesday challenge" posting a black square, but they never apologized to Colin Kaepernick. Apologize to him first and then we will take you seriously. 
$\mathrm{BM} \# 3$

I understand why some people have a problem with the name Black Lives Matter because it is too focused on Black people even though it is about everybody, and is an inclusive organization. The BLM movement is all about emphasizing that everybody is human, and that you can't forget about somebody because of their skin color. Inside of the police force, we know that the police protect their own, pretty similar to how gang members don't believe in snitching. But it was good to see that people genuinely cared about what happened. It made me feel positive about the future, seeing that police reform is starting to come to the forefront of people's minds and people aren't defending police as much anymore.

BM \#4 It's important to speak not just about BLM but about "Blue Lives Matter" so that all opinions can be heard. But I do feel like racist incidents fall on deaf ears in "Blue Lives Matter" supporters because they feel BLM isn't about them, so they don't care about the movement. You see White support when the issue is trending, but not after the moment has passed.

We need to defund police and instead put resources into community programs and putting Black officers in Black neighborhoods so we feel safe. The police have always known that they have back up from other officers and feel empowered to abuse their power. Defunding them takes back control for Black neighborhoods where residents are used to fighting for their rights in a system that works against them but always stands behind police. Defunding them puts community residents on more equal footing with police in a system that doesn't have our back.

BM \#5 The BLM movement is inspirational, but unfortunately I see a majority of it as a trend when it needs to be an everyday thing. If someone calls the police because of forged money, weapons don't need to be drawn. If someone is trying to steal using fake money, just get him out of there. If he is resisting, of course some force may need to be applied, but Derek Chauvin was forcibly trying to hurt George Floyd. Black lives certainly do matter, yet we continue to have to say, "Oh look! There goes another Black person murdered, missing, or lynched", and it's exhausting. I truly hope that one day society will just be able to recognize African Americans as equal. Because it is draining, it is very draining.

BM \#6 BLM is a necessary movement Black people have been fighting for a really long time, pointing out the injustices that they face on a day-to-day basis, and how they are endangered every single day. It's based on both Dr. Martin Luther King and Malcolm X. MLK, Jr., was all about peaceful protests and pounding the pavement but in a peaceful manner, countering hate with love. Malcolm $X$ was on the other end of the spectrum, "By any means necessary", so without Malcolm $X$ with his extremism, passion, and drive, we wouldn't make White people feel uncomfortable and challenged-the only way that change will happen.

But BLM is not counter-White people, but asking White people to value the lives of Black people just like we do for the majority. Defunding is not abolishing the police, just taking money and allocating it to other communities. Then there is the opposite of defunding the police-reforming the police by pouring more money into the police force for better and longer training.

People get really impassioned about being a part of protests, to feel like they belong. I saw White girls dressed with helmets and bats at a protest, like it was a block party. People don't really know why they are there. To make people in positions of power uncomfortable, we have to continuously educate and have these conversations. We have to pound the pavement to make sure that people don't forget about it because that interest dies off.

It's sad that there is so much systemic racism with a hierarchy where people cannot act on their morals without having to risk their job. If one of those officers had spoken up to prevent Floyd's death, they would have lost their job. People will not be willing to hold each other accountable until the entire system is corrected. 


\begin{tabular}{|c|c|}
\hline WHITE FEMALES & \\
\hline WF \#1 & $\begin{array}{l}\text { BLM street protests call attention to the issue but does not tell people what to do. } \\
\text { Where do we go from here? Now what? A lot of White people can feel helpless as to } \\
\text { what to do and how to be an ally. How do we deal with reliance on people in power } \\
\text { that make it hard to enact change? } \\
\text { Defunding the police is knee-jerk in one direction and is more saying what we don't } \\
\text { want rather than what we do want. We do need to have police but POC need to feel } \\
\text { safe, even though I don't know what that looks like for them. }\end{array}$ \\
\hline WF \#2 & $\begin{array}{l}\text { The BLM movement is entirely necessary for the advancement of equality in policing. } \\
\text { We hear "All Lives Matter", but that can't be possible until systemic racism and } \\
\text { implicit biases are removed from all workplaces, and we address the treatment of } \\
\text { minorities while interacting with police officers and in the court system. The death of } \\
\text { George Floyd reflects the need to revamp the entirety of the police system. There was } \\
\text { an officer involved in the murder of George Floyd who was hesitant to be involved } \\
\text { but still participated in guilty acts. There is no way to screen out individuals who } \\
\text { would abuse their power and no way to know or predict how a person would react in } \\
\text { different circumstances. }\end{array}$ \\
\hline
\end{tabular}

WF \#3 The Black Lives Matter movement started off really well, helping other communities like the White community see racism in America and the unfair treatment of Black people. However, with every movement comes backlash, like saying "all lives matter". That is true but that is not what the movement is trying to say. They weren't bashing other ethnic groups but saying, "hey, Black people matter too and we are not treated correctly". People need to stop viewing things as blaming them personally.

WF \#4 Overall, I understand and agree with the reasoning for creating the Black Lives Matter movement. However, I feel like some followers of the movement have begun to lose their way by criticizing people they think don't support the movement. So while I completely understand BLM and fully support it, it is creating a divide in the nation rather than the unity that was originally intended.

Also, while it's truly sickening and terrifying that officers like [Chauvin] are out there, the popular ACAB [all cops are bastards] movement and its push to "defund the police" is just like putting a band-aid on the issue.

WF \#5 I think the intentions of the Black Lives Matter are good, but I also saw a lot negativity coming from it. Unfortunately that's what fuels the news and social media as well. I don't think rioting supports BLM. I saw a lot of White people and business owners bashed for not saying anything because it's as if they don't care and aren't supportive if they are quiet. I saw a lot of posts about how the silence is "deafening and discouraging", but at the same time, if someone did speak on something, they got bashed and called racist because they didn't say it correctly and that our "White privilege" was showing. Maybe White people are quiet because we are watching and learning and trying to recognize our "White privilege" we were taught to ignore by society and our families so we can make a change.

Police need to be held to higher standards and be held accountable for their actions. There is no reason for a police officer with a history of complaints to still be employed as a police officer. Not only do police need to change when it comes accountability and culture, but they also should receive extra training such as about racial bias, problem-solving skills, conflict mediation, and de-escalation tactics. I think George Floyd's death is a catalyst that will help revamp policing and police abuse of power. 
The movement is doing really good things by addressing people's differences and how everyone should be treated the same no matter what they look like. But too often we hear about all of the negative things that police officers do, since the media doesn't show enough of the good things they do daily because people want to hear about all of the bad things going on in the world. However, there is still a need to fix what the police do because they are far from perfect. People should talk more and be better educated about this instead of treating it as taboo and argument provoking. Although I will never fully be able to see something like this from their point of view, I like to educate myself on different points of view so I can make an educated judgment.

\section{BLACK FEMALES}

BF \#1 People wonder, "How can this happen?", but police brutality has always been there, even if people just haven't been aware of it or older people have turned a blind eye. Some people don't realize the long-standing tension that has gotten pushed to the background as normal, so it's hard for them to see it, like when Black people get labeled as thugs. History is repeating itself. My grandmother (in her mid-50s) compared it to when NWA came out with their " $\mathrm{F}^{* * *}$ the police" song [1988]. But with this new, more progressive generation, there is now a chance for change. Black people will be more able to just live their lives.

BF \#2 The movement and the protections for Black people are needed. People need to understand that BLM isn't saying that black people's lives matter more than others; it's saying that they should be valued as much as anyone else. I also don't appreciate people claiming that BLM is a cult. It's a group that advocates for black people because we feel that we're not advocated for in society. BLM isn't about dividing the country, but about uniting it. It's a shame that it took Floyd's death for people to realize that things have been happening like this for a long time. Why is it that black people being continuously killed seems to be necessary for non-POC to realize what we've been fighting for?

BF \#3: $\quad$ BLM is a good movement, but it'd be better if we focused more on POC—not just Black people. Also, there's a lot of Black-on-Black crime. Do Black Lives Matter if y'all killing each other? Why does it seem like BLM matters only when a White police officer is involved in killing a Black person? Our lives should matter all the time, regardless of the involvement of an authority figure like a police officer or the race of the killer. We should be as upset by Black-on-Black deaths, even when it gets less media attention, like when it happens because of a beef between two people. We should be preventing Black deaths and not limiting our outrage to when it's caused by racist police officers who seem to be able to get away with it or only get charged with a minor offense.

BF \#4 The BLM movement is necessary for a country built from such a bloody background. It allows racial issues that were once taboo to transform into mainstream topics for the masses. George Floyd's death represented the systemic abuse of black people, which leads to our militarized police taking extreme and unneeded action. George Floyd's death is one of the countless deaths of an innocent African American in 2020 alone. We need to reform our police due to this happening so regularly.

BF \#5 The Black Lives Matter movement is simply a movement to increase awareness of the growth in killings of Black men and women when compared to any other race, whether it's due to police brutality or murders of Black men and women by civilians. BLM is not a terrorist movement when its mission is to bring awareness to this problem that a lot of people want to ignore. 
$\mathrm{BF} \# 6$

Black people are treated like their lives don't matter and that they bring down society (for example because of gangs and drugs). As Black people, we also get questioned because we don't get a basic level of respect or credibility. But we mostly need the movement because of how White police officers treat Black people. I have to think extra hard when I encounter police because I go in with the idea that they could harm me rather than protect me. Unfortunately, I don't know how fix this-how to train police to treatment people equally.

\section{References}

Acevedo, John. 2020. Reclaiming Black Dignity (June 10, 2020). University of Alabama Legal Studies Research Paper No. 3624197, June 10. Available online: https://ssrn.com/abstract=3624197 (accessed on 5 November 2020).

Anderson, Monica. 2016. The Hashtag \#BlackLivesMatter Emerges: Social Activism on Twitter. August 15. Available online: https://www.pewresearch.org/internet/2016/08/15/the-hashtag-blacklivesmatter-emergessocial-activism-on-twitter/ (accessed on 6 November 2020).

Anspach, Nicolas M. 2017. The new personal influence: How our Facebook friends influence the news we read. Political Communication 34: 590-606. [CrossRef]

Bailey, Holly. 2020. Body cam transcripts give fuller picture of Floyd's fear. Officer told Floyd his pleas for breath were wasting it. Washington Post, July 8. Available online: https://www.washingtonpost.com/national/ george-floyd-death-transcripts/2020/07/08/a7050efe-c15c-11ea-b178-bb7b05b94af1_story.html(accessed on 5 November 2020).

Barroso, Amanda. 2019. How often people talk about race with family and friends depends on racial and ethnic group, education, politics. Pew Research Center, June 25. Available online: https:/www.pewresearch.org/facttank/2019/06/25/how-often-people-talk-about-race-with-family-and-friends/(accessed on 11 November 2020).

Boczkowski, Pablo J., Eugenia Mitchelstein, and Mora Matassi. 2018. "News comes across when I'm in a moment of leisure": Understanding the practices of incidental news consumption on social media. New Media $\mathcal{E}$ Society 20: 3523-39.

Bordonaro, Francesca, and Dale Willits. 2018. The Effects of Police-Caused Black Deaths on Media Coverage and Public Interest in the Movement. Journal of Criminal Justice $\mathcal{E}$ Law 2: 102-21.

Bowman, Michael. 2017. TV, cell phones and social justice: A historical analysis of how video creates social change. Race, Gender \& Class 24: 16-26.

Brewer, Sierra, and Lauren Dundes. 2018. Concerned, meet terrified: Intersectional feminism and the Women's March. Women's Studies International Forum 69: 49-55. [CrossRef]

Calvert, Collin M., Sonya S. Brady, and Rhonda Jones-Webb. 2020. Perceptions of violent encounters between police and young Black men across stakeholder groups. Journal of Urban Health 97: 275-95. [CrossRef]

Cappelli, Mary Louisa. 2020. Black Lives Matter: The Emotional and Racial Dynamics of the George Floyd Protest Graffiti. Advances in Applied Sociology 9: 323-46. [CrossRef]

Carney, Nikita. 2016. All lives matter, but so does race: Black lives matter and the evolving role of social media. Humanity \& Society 40: 180-99.

Clark, Meredith D., Dorothy Bland, and Jo Ann Livingston. 2017. Lessons from\# McKinney: Social media and the interactive construction of police brutality. The Journal of Social Media in Society 6: 284-313.

Clement, J. 2020. Number of monthly active Facebook users worldwide as of 2nd quarter 2020. Statista, August 10. Available online: https://www.statista.com/statistics/264810/number-of-monthly-active-facebookusers-worldwide/\#: \{\}:text=With\%20over\%202.7\%20billion\%20monthly,network\%20ever\%20to\%20do\% 20so(accessed on 5 November 2020).

Cox, Jonathan M. 2017. The source of a movement: Making the case for social media as an informational source using Black Lives Matter. Ethnic and Racial Studies 40: 1847-54. [CrossRef]

Crabtree, Steve. 2020. Gallup. Politics. Most Americans Say Policing Needs 'Major Changes'. July 22. Available online: https://news.gallup.com/poll/315962/americans-say-policing-needs-major-changes.aspx (accessed on 5 November 2020).

Cross, Susan E., and Laura Madson. 1997. Models of the self: Self-construals and gender. Psychological Bulletin 122: 5-37. [CrossRef] [PubMed] 
O’Dea, Conor J., Steven T. Chalman, Angelica M. Castro Bueno, and Donald A. Saucier. 2018. Conditional aggression: Perceptions of male violence in response to threat and provocation. Personality and Individual Differences 131: 132-41. [CrossRef]

DiMuccio, Sarah H., and Eric D. Knowles. 2020. The political significance of fragile masculinity. Current Opinion in Behavioral Sciences 34: 25-28. [CrossRef]

Dukes, Kristin Nicole, and Sarah E. Gaither. 2017. Black racial stereotypes and victim blaming: Implications for media coverage and criminal proceedings in cases of police violence against racial and ethnic minorities. Journal of Social Issues 73: 789-807. [CrossRef]

Eysenbach, Gunther, and James E. Till. 2001. Ethical issues in qualitative research on internet communities. BMJ 323: 1103-5. [CrossRef] [PubMed]

Facebook. 2020. Data Policy. Available online: https://www.facebook.com/policy.php (accessed on 1 September 2020).

Fernandez, Manny, and Audra D. S. Burch. 2020. George Floyd, from 'I want to touch the world' to 'I can't breathe'. New York Times, June 9. Available online: https://www.nytimes.com/2020/06/08/us/george-floydwho-is.html(accessed on 5 November 2020).

Fletcher, Richard, and Rasmus Kleis Nielsen. 2018. Are people incidentally exposed to news on social media? A comparative analysis. New Media \& Society 20: 2450-68.

Fowler, Stephanie L., and Andrew L. Geers. 2017. Does trait masculinity relate to expressing toughness? The effects of masculinity threat and self-affirmation in college men. Psychology of Men \& Masculinity 18: 176-86.

Goffman, Erving. 1959. The Presentation of Self in Everyday Life. New York: Random House.

Graham, Amanda, Murat Haner, Melissa M. Sloan, Francis T. Cullen, Teresa C. Kulig, and Cheryl Lero Jonson. 2020. Race and Worrying About Police Brutality: The Hidden Injuries of Minority Status in America. Victims $\mathcal{E}$ Offenders 15: 549-73.

Harlow, Roxanna, and Lauren Dundes. 2004. “United” We Stand: Responses to the September 11 attacks in Black and White. Sociological Perspectives 47: 439-64. [CrossRef]

Hehman, Eric, Jessica K. Flake, and Jimmy Calanchini. 2018. Disproportionate use of lethal force in policing is associated with regional racial biases of residents. Social Psychological and Personality Science 9: 393-401. [CrossRef]

Hopp, Toby, Patrick Ferrucci, Chris J. Vargo, and Jolene Fisher. 2020. Exposure to Difference on Facebook, Trust, and Political Knowledge. Mass Communication E Society 23: 779-809.

Horowitz, Juliana M., and Gretchen Livingston. 2016. How Americans view the Black Lives Matter movement. Pew Research, July 8. Available online: https://www.pewresearch.org/fact-tank/2016/07/08/how-americansview-the-black-lives-matter-movement/(accessed on 5 November 2020).

Jackson, Brandon A. 2018. Beyond the cool pose: Black men and emotion management strategies. Sociology Compass 12: 1-14. [CrossRef]

Jackson, Brandon A., and Adia H. Wingfield. 2013. Getting angry to get ahead: Black college men, emotional performance, and encouraging respectable masculinity. Symbolic Interaction 36: 275-92. [CrossRef]

Johnson, James, and Len Lecci. 2020. How caring is "nullified": Strong racial identity eliminates White participant empathy effects when police shoot an unarmed Black male. Psychology of Violence 10: 58-67. [CrossRef]

Juhasz, Alexandra. 2016. How do I (not) look? Live feed video and viral black death. Jstor Daily, July 20. Available online: https://daily.jstor.org/how-do-i-not-look/(accessed on 7 November 2020).

King, Bernice. 2020. Be a King @BerniceKing. 10:39 PM, August 23. Available online: https:/twitter.com/ BerniceKing/status/1297725252697546752 (accessed on 5 November 2020).

Lake, Jaboa Shawntaé, Aurelia T. Alston, and Kimberly Barsamian Kahn. 2018. How Social Networking Use and Beliefs About Inequality Affect Engagement with Racial Justice Movements. Race and Justice, 1-20. [CrossRef]

Levan, Kristine, and Kelsey Stevenson. 2019. 'There's Gonna Be Bad Apples': Police-Community Relations through the Lens of Media Exposure Among University Students. International Journal for Crime, Justice and Social Democracy 8: 83-105. [CrossRef]

Levitz, Jennifer, Erin Ailworth, and Tawnell D. Hobbs. George Floyd and Derek Chauvin: The Lives of the Victim and His Killer. Wall Street Journal, June 21. Available online: https://www.wsj.com/articles/george-floyd-andderek-chauvin-the-lives-of-the-victim-and-his-killer-11592761495(accessed on 10 October 2020).

Mchunu, Koyi. 2020. Roadside death memorials revisited: Mourning in public spaces. Cogent Arts $\mathcal{E}$ Humanities, 7. [CrossRef] 
Miethe, Terance D., Olesya Venger, and Joel D. Lieberman. 2019. Police use of force and its video coverage: An experimental study of the impact of media source and content on public perceptions. Journal of Criminal Justice 60: 35-46. [CrossRef]

Mincey, Krista, Moya Alfonso, Amy Hackney, and John Luque. 2015. The influence of masculinity on coping in undergraduate black men. The Journal of Men's Studies 23: 315-30. [CrossRef]

Mohrman, K., and Mia Fischer. 2016. Black deaths matter? Sousveillance and the invisibility of black life. Ada: A Journal of Gender, New Media, and Technology 10: 1-13.

Moreno, Megan A., Natalie Goniu, Peter S. Moreno, and Douglas Diekema. 2013. Ethics of social media research: Common concerns and practical considerations. Cyberpsychology, Behavior, and Social Networking 16: 708-13. [CrossRef] [PubMed]

Motley, Robert O., Jr., Yu-Chih Chen, Carnayla Johnson, and Sean Joe. 2020. Exposure to Community-Based Violence on Social Media among Black Male Emerging Adults Involved with the Criminal Justice System. Social Work Research 44: 87-97. [CrossRef]

O'Neal, Lonnae. 2020. George Floyd's mother was not there, but he used her as a sacred invocation. The Undefeated, May 28. Available online: https://theundefeated.com/features/george-floyds-death-mother-was-not-therebut-he-used-her-as-a-sacred-invocation/(accessed on 5 November 2020).

Omnicore. 2020. Facebook by the Numbers: Stats, Demographics \& Fun Facts. April 22. Available online: https://www.omnicoreagency.com/facebook-statistics/ (accessed on 5 November 2020).

Owusu-Bempah, Akwasi. 2017. Race and policing in historical context: Dehumanization and the policing of Black people in the 21st century. Theoretical Criminology 2: 23-34. [CrossRef]

Pannett, Rachel, James Marson, and Gabriele Steinhauser. 2020. George Floyd's Death in U.S. Sparks Outcry Abroad. Wall Street Journal, June 3. Available online: https://www.wsj.com/articles/george-floyds-death-in-us-sparks-outcry-abroad-11591123234(accessed on 5 November 2020).

Pirtle, Whitney N. Laster. 2020. Racial capitalism: A fundamental cause of novel coronavirus (COVID-19) pandemic inequities in the United States. Health Education \& Behavior. Available online: https://www.ncbi. nlm.nih.gov/pmc/articles/PMC7301291/ (accessed on 5 November 2020).

Reinka, Mora A., and Colin Wayne Leach. 2017. Race and reaction: Divergent views of police violence and protest against. Journal of Social Issues 73: 768-88. [CrossRef]

Rho, Eugenia Ha Rim, and Melissa Mazmanian. 2019. Hashtag Burnout? A Control Experiment Investigating How Political Hashtags Shape Reactions to News Content. Proceedings of the ACM on Human-Computer Interaction 3: 1-25. [CrossRef]

Robertson, Shandria, and Lauren Dundes. 2017. Anger matters: Black female student alienation at predominantly white institutions. Race and Pedagogy Journal: Teaching and Learning for Justice 2: 3. Available online: https: //soundideas.pugetsound.edu/cgi/viewcontent.cgi?article=1020\&context=rpj (accessed on 5 November 2020).

Russonello, Giovanni. 2020. Have Americans Warmed to Calls to ‘Defund the Police’? New York Times, July 3. Available online: https://www.nytimes.com/2020/07/03/us/politics/polling-defund-the-police.html(accessed on 5 November 2020).

Shaw, Sono, and Regina Widjaya. 2020. Posts Mentioning 'Black Lives Matter' Spiked on Lawmakers' Social Media Accounts after George Floyd Killing. July 16 . Available online: https://www.pewresearch.org/fact-tank/2020/07/16/posts-mentioning-black-lives-matter-spikedon-lawmakers-social-media-accounts-after-george-floyd-killing/ (accessed on 5 November 2020).

Small, Stacey S. 2020. Personal communication with poet Stacey Small, McDaniel College. @staceysharea. September 2.

Smiley, CalvinJohn, and David Fakunle. 2016. From "brute" to "thug:" The demonization and criminalization of unarmed Black male victims in America. Journal of Human Behavior in the Social Environment 26: 350-66. [CrossRef]

Stewart, Nikita. 2020. Black Activists Wonder: Is Protesting Just Trendy for White People? New York Times.com, June 26. Available online: https://www.nytimes.com/2020/06/26/nyregion/black-lives-matter-White-peopleprotesters.html(accessed on 13 November 2020).

Stratmoen, Evelyn, Tiffany J. Lawless, and Donald A. Saucier. 2019. Taking a knee: Perceptions of NFL player protests during the National Anthem. Personality and Individual Differences 137: 204-13. [CrossRef] 
Tillery, Alvin B. 2019. What Kind of Movement is Black Lives Matter? The View from Twitter. Journal of Race, Ethnicity and Politics 4: 297-323. Available online: https://www.cambridge.org/core/journals/journal-ofrace-ethnicity-and-politics/article/what-kind-of-movement-is-black-lives-matter-the-view-from-twitter/ 375801268123BCA397284EFBE36C9F4E (accessed on 5 November 2020). [CrossRef]

Tisby, Jemar. 2020. The Familial Language of Black Grief. The Atlantic, June 10. Available online: https://www. theatlantic.com/family/archive/2020/06/familial-language-black-grief/612847/(accessed on 5 November 2020).

Torres, Sasha. 2003. Black, White, and in Color: Television and Black Civil Rights. Princeton: Princeton University Press.

Tufekci, Zeynep. 2018a. Twitter and Tear Gas: The Power and Fragility of Networked Protest. New Haven: Yale University Press.

Tufekci, Zeynep. 2018b. How social media took us from Tahrir Square to Donald Trump. MIT Technology Review. Available online: https://rws511.pbworks.com/w/file/fetch/135165753/Tufecki\%20social\%20media\%20from\% 20Tahrir\%20Square.pdf (accessed on 9 November 2020).

Umamaheswar, Janani. 2020. Policing and Racial (In) Justice in the Media: Newspaper Portrayals of the "Black Lives Matter" Movement. Civic Sociology. [CrossRef]

Vaidhyanathan, Siva. 2018. Antisocial Media: How Facebook Disconnects Us and Undermines Democracy. Oxford: Oxford University Press.

Vandello, J. A., and J. K. Bosson. 2013. Hard won and easily lost: A review and synthesis of theory and research on precarious manhood. Psychology of Men E Masculinity 14: 101-13. [CrossRef]

Watson, Marlene F., William L. Turner, and Paulette Moore Hines. 2020. Black Lives Matter: We are in the Same Storm but we are not in the Same Boat. Family Process. [CrossRef]

Watson, Ryan. 2019. In the Wakes of Rodney King: Militant Evidence and Media Activism in the Age of Viral Black Death. The Velvet Light Trap 84: 34-49. [CrossRef]

Weaver, Kevin S., and Theresa K. Vescio. 2015. The justification of social inequality in response to masculinity threats. Sex Roles 72: 521-35. [CrossRef]

Whitfield, Stephen J. 1991. A Death in the Delta: The Story of Emmett Till. Baltimore: JHU Press.

Wilkins, Denise J., Andrew G. Livingstone, and Mark Levine. 2019. Whose tweets? The rhetorical functions of social media use in developing the Black Lives Matter movement. British Journal of Social Psychology 58: 786-805. [CrossRef]

Willis, Roxana. 2019. Observations online: Finding the ethical boundaries of Facebook research. Research Ethics 15: 1-17. [CrossRef]

Zurcher, Anthony. 2020. BBC: George Floyd Death: Violence Erupts on Sixth Day of Protests. June 1. Available online: https://www.bbc.com/news/world-us-canada-52872401 (accessed on 5 November 2020).

Publisher's Note: MDPI stays neutral with regard to jurisdictional claims in published maps and institutional affiliations.

(C) 2020 by the authors. Licensee MDPI, Basel, Switzerland. This article is an open access article distributed under the terms and conditions of the Creative Commons Attribution (CC BY) license (http://creativecommons.org/licenses/by/4.0/). 